\title{
Experience of morphofunclional indices use at fish health control in aquaculture
}

\author{
Nina Golovina ${ }^{1,2, *}$, Natalia Romanova ${ }^{1,2}$, and Valentina Varaksina $^{2}$ \\ ${ }^{1}$ Dmitrov Fish Farming Industrial Institute (Branch), FSBEI “Astrakhan State Technical University" \\ Moscow area, Dmitrov region, 141821 Rybnoe, Russia \\ ${ }^{2}$ All-Russian Institute of Fisheries and Oceanography («VNIIPRKh») Moscow area, Dmitrov region, \\ 141821 Rybnoe, Russia
}

\begin{abstract}
Results of work have been summarized on use of some morphofunclional indices at fish health control in aquaculture. Their use helps efficiently and intravitally estimate and reject sick specimen having a low immune status. It has been revealed that the most important but labourintensive indices are hematological ones which can be changeable at deseases of various nature and may be used at appraisal of stress-response. Indices of hemoglobin content, erythrocytes and leukocytes numbers, erythropoeitic activities, leukocytal formula as well as the absolute quantity of different leukocytes groups are informative characteristics for efficient control. The express-method of fish stress aiagnostics has been developed and worked through with application of gluco-and multisticks for estimation of 10 biochemical parameters in mucus and of glucose in blood within 2 or 3 minutes. It has bees shown that the level of a non-specific resistance and adaptive possibilifies of some specimen affect heterogeneity of indices values determined what allows to reveal the part of weakened specimen and to estimate necessity of correcting activities as well as to predict the result of the situation formed with reared fish.
\end{abstract}

\section{Introduction}

At present, great attention is paid to aquaculture development in the Russian Federation. By 2030, it is proposed to rear about 400 tsd t of marketable fish, at industrial farms at least 150 tsd t. It would provide the national food sustainability, reach the average annual fish and fish products consumption of about $22-27 \mathrm{~kg} /$ person, as well as $80-90 \%$ index of self-prosperity. The most heavy damage to aquaculture cause diseases developing in hydrobionts during their rearing.

In this connection, the health control of aquaculture objects reared seems to be an important technological chain allowing to esfimate the epizootic situation and to correct the process of medicinal and preventive measures. At health appraisal of cultivated fish, different markers are used which reflect its physiological state [1-3]. The most spread of them for such aims are haemathological indices which sensitivity helps estimate influence of different

*Corresponding author: kafvba@mail.ru 
factors on organism including toxics [4-6].

The near functional relationship of fish blood with metabolic processes in organism allows to reveal changes connected with breach of piscicultural-normative requirements of rearing biotechnic, deterioration of water quality as well as with stress situations formed at manipulation. Stress factors lead to decrease of non-specific organism's resistance, receptivity to opportunistically pathogenic infestants which result mostly in chronic desease leading to decrease of growth rate and even to fish death [7-9]. In these circumstances, clinical signs would not always develop, but the delay of prophylactic measures and therapy leads to loss of fish production [10-11].

In the world literature, different sides of fish immunity study have been reflected. Such blood characteristics as hormon level, cell and humoral factors have been investigated best of all [12-15]. As for mucus, being the first defense line, the most number of publications are devoted to alterations of its bacterial activity and lysozyme level [16-18]. Others mucus indices at stress loading were not determined.

The up-to-date investigation directions in ichthyopathology are the following: development of methods of health state assessment for aquaculture objects reared, expressive methods of diseases diagnostics, search of the most informative indices reflecting aftereffects of stress impacts. The aim of this work is the search of the most informative and expressive methods of fish health assessment at aquacultural fish rearing.

\section{Material and methods}

The material was collected in fish farms specialized with fish rearing at different technologies. The investigation objects were the Siberian sturgeon (Acipenser baerii), carp (Cyprinus carpio), rainbow trout (Oncorhynchus mykiss), channel catfish (Ictalurus punctatus), the Caspian salmon (Salmo caspius), common whitefish (Coregonus lavaretus), muksun (Coregonus muksun). Sampling was carried out using not only clinical healthy fish, but also at such diseases as: swim bladder inflammation, dactylogyrosis, bothriocephalesic, aeromonosis, branchiomycosis, mycotoxicosis in carp; cryptobiosis of the Caspian salmon; myxobacteriosis in the Siberian salmon and rainbow trout; gasbubble disease in carp, trout and salmon, saprolergniosis of bighead carp.

Experiments on stress-response estimation for trout, carp, bighead carp, the Siberian sturgeon, grass carp were carried out under onder experimental and industrial conditions. The common number of fish examined was 6,179 specimen.

Biochemical parameters of the external mucus and the blood glucose were measured by a semiquantitative express-method with indication test-sticks («Multistix» and «Glucostix» of «Bayer» firm). Data reading from the sticks was carried out with «Clinetek-50» device and «Glucometer GH». The mucus indices were estimated as follows: glucose, bilirubin, ketones, specific weight, hemoglobin (erythrocytes presence), $\mathrm{pH}$, protein, urobilinogen, nitrites, leukocytes).

The hematological analysis included determination of main characteristics by agreedupon methods: protein content in blood serum, hemoglobin concentration, hematocrit, leukocrit, number of erythrocytes, erythropoietic activities (numbers of young erythrocytes forms), the absolute erythrocytes numbers and the leukocytic formula.

The statistical data processing was carried out by the program sets «Statistica 8.0.» and «Excel-2007».

\section{Results}

The summarizing of the gained experience on morphofunctional indices use at fish health 
control in aquaculture allowed to appraise their informativity and diagnostic importance.

The most used characteristics reflect objectively the physiological organism's state of fish reared and can be applicated as biomarkers of physiological norm of healthy fish when rearing conditions are optimal. The mean of any index for hematological norm is within confidence level variations of its group mean error and does not fall off from this level by $10 \%$. The most informative blood characteristics are the following: common protein and glucose level, hemoglobin content, erythrocytes number, erythropoiese activities (young erythrocites' forms number) absolute leukocytes number and the leukocytic formula.

As for mucus, they are bilirubin, hemoglobin (erythrocytes presence), ketones and protein. The table 1 shows mucus characteristics of some aquaculture objects as physiological norm.

Table 1. Biochemical mucus composition for two-summer-old fish species reared in aquuaculture

\begin{tabular}{|c|c|c|c|c|c|c|}
\hline Indices & $\begin{array}{c}\text { Bighead } \\
\text { carp }\end{array}$ & Carp & $\begin{array}{c}\text { Rainbow } \\
\text { trout }\end{array}$ & $\begin{array}{c}\text { Caspian } \\
\text { salmon } \\
\text { (trout) }\end{array}$ & $\begin{array}{c}\text { Atlantic } \\
\text { salmon }\end{array}$ & $\begin{array}{c}\text { Lena } \\
\text { salmon }\end{array}$ \\
\hline Bilirubin, ye & & - & - & -+ & - & ++ \\
\hline $\begin{array}{c}\text { Specific } \\
\text { weignt, g/m }\end{array}$ & $\begin{array}{c}1.010- \\
1.030\end{array}$ & $\geq 1.030$ & $\begin{array}{c}1.0005- \\
1.020\end{array}$ & $\begin{array}{c}1.025- \\
1.030\end{array}$ & $\begin{array}{c}1.020- \\
1.025\end{array}$ & $\begin{array}{c}1.015- \\
1.025\end{array}$ \\
\hline $\begin{array}{c}\text { Ketones, } \\
\text { mmol/1 }\end{array}$ & $1.0-2.0$ & traces & $\begin{array}{c}\text { traces }- \\
0.5\end{array}$ & - & - & + \\
\hline $\begin{array}{c}\text { Erythrocytes } \\
\text { er./mcl }\end{array}$ & $10-80$ & $0-10$ & $10-80$ & $0-10$ & $-25-80$ & $80-200$ \\
\hline Protein, g/l & $1.1-2.0$ & $0.3-1.0$ & $0.1-1.0$ & $0-0.3$ & $0.3-1.0$ & $0-0.3$ \\
\hline $\mathrm{pH}$ & $5.0-7.5$ & $6.5-7.0$ & $5.0-7.0$ & $5.5-6.0$ & $5.0-6.0$ & $5.0-6.5$ \\
\hline $\begin{array}{c}\text { Leukocytes, } \\
\text { lk/mcl }\end{array}$ & - & $0-15$ & - & - & - & $1-15$ \\
\hline
\end{tabular}

note: - the parameter is not measured;

+ and ++- reaction estimated by representative units.

Value of blood indices reflects the individual fish adaptation to environmental factors.

Their diagnostic value is determined by variability which points out physiological heterogeneity of fish reared. The presence of an individual reaction while forming adaptive mechanisms to negative impacts of some biotic and abiotic environmental factors, including feeds used, is not taken into accout in practical fish farming. We suggest to bring into use equally with «physiological norm», the conception of «technological norm» which supplements the size-age standard and is attached to fish cultivation technology.

Table 2 adduces haemathological characteristics of one-summer-old carps reared at different technologies which may be used as technological norm for fish group of the same age. These parameters reflect objectively physiological fish state and may be used as biomarkers, characterizing adaptive possibilities of fish organism, as well as reflect optimal rearing conditions.

Alteration of average group values of haemathological indices under influence of factors, connecter with rearing technology, is expressed in adaptive mechanisms which satisfy organism's requirements promoting its optimum growth. Values of the technological norm can deviate from indices of physiological norm by $20-40 \%$.

Table 2. Haemathological indices of one-summer-old carps reared at different technologies

\begin{tabular}{|c|c|c|c|c|c|}
\hline \multirow[t]{2}{*}{ Indices } & \multicolumn{2}{|c|}{ Ponds } & \multirow[t]{2}{*}{ Cages } & \multirow[t]{2}{*}{ Tanks } & \multirow[t]{2}{*}{ RAS* } \\
\hline & $\begin{array}{l}\text { Extensive } \\
\text { technology }\end{array}$ & $\begin{array}{l}\text { Intensive } \\
\text { technology }\end{array}$ & & & \\
\hline
\end{tabular}




\begin{tabular}{|c|c|c|c|c|c|}
\hline 1 & 2 & 3 & 4 & 5 & 6 \\
\hline Hemoglobin, g/l & $85.1 \pm 2.3$ & $78.1 \pm 4.5$ & $\begin{array}{l}89.0 \pm \\
2.4\end{array}$ & $\begin{array}{c}75.4 \pm \\
4.3\end{array}$ & $\begin{array}{l}59.5 \pm \\
3.4\end{array}$ \\
\hline 1 & 2 & 3 & 4 & 5 & 6 \\
\hline $\begin{array}{c}\text { Erythrocytes, } \\
\mathrm{mln} / \mathrm{mcl}\end{array}$ & $1.5 \pm 0.004$ & $1.35 \pm 0.4$ & $\begin{array}{c}1.09 \pm \\
0.04\end{array}$ & $1,3 \pm 0,2$ & $\begin{array}{l}1.0 \pm \\
0.04\end{array}$ \\
\hline $\begin{array}{l}\text { Haemathocrit, } \\
1 / 1 * 10^{-2}\end{array}$ & $39.9 \pm 1.1$ & $36.2 \pm 0.2$ & $\begin{array}{c}35.4 \pm \\
0.2\end{array}$ & $\begin{array}{c}34.1 \pm \\
1.0\end{array}$ & $\begin{array}{l}30.6 \pm \\
1.6\end{array}$ \\
\hline $\mathrm{MCH}^{* *}, \mathrm{nr}$ & $56.7 \pm 2.7$ & $46.3 \pm 1.9$ & $\begin{array}{c}81.6 \pm \\
2.3 \\
\end{array}$ & $\begin{array}{c}58.0 \pm \\
4.0 \\
\end{array}$ & $\begin{array}{c}59.6 \pm \\
1.6 \\
\end{array}$ \\
\hline $\begin{array}{c}\text { ESR (Erythrocytes } \\
\text { Sedimentation } \\
\text { Rate) }, \mathrm{mcm}^{3}\end{array}$ & $268.7 \pm 10.6$ & $342.5 \pm 2.8$ & $\begin{array}{c}324.7 \pm \\
2.7\end{array}$ & $\begin{array}{c}349.6 \pm \\
7.3\end{array}$ & $\begin{array}{c}303.3 \pm \\
0.9\end{array}$ \\
\hline $\begin{array}{l}\text { Leukocytes, } \\
\text { tsd } / \mathrm{mcl}\end{array}$ & $24.5 \pm 4.3$ & $37.5 \pm 5.2$ & $\begin{array}{c}41.0 \pm \\
4.5\end{array}$ & $\begin{array}{c}39.4 \pm \\
4.3\end{array}$ & $\begin{array}{l}52.7 \pm \\
0.2 \\
\end{array}$ \\
\hline \multicolumn{6}{|l|}{$\begin{array}{l}\text { Leukocytic } \\
\text { formula, } \%\end{array}$} \\
\hline Blasts & $0.6 \pm 0.4$ & 0 & $0.4 \pm 0.1$ & $1.7 \pm 0.2$ & $2.1 \pm 0.3$ \\
\hline Neutrophils & $1.6 \pm 0.2$ & $15.5 \pm 1.6$ & $3.2 \pm 1.0$ & $2.8 \pm 0.7$ & $2.0 \pm 0.3$ \\
\hline $\begin{array}{c}\text { Eosinophils and } \\
\text { pseudoeosinophils }\end{array}$ & $3.7 \pm 1.2$ & $4.0 \pm 0.09$ & 0 & 0 & 0 \\
\hline $\begin{array}{c}\text { Basophils and } \\
\text { pseudobasophils }\end{array}$ & $3.6 \pm 0.8$ & $3.5 \pm 1.4$ & 0 & $1.0 \pm 0.5$ & $1.6 \pm 0.4$ \\
\hline Foamy cells & $0.7 \pm 0.3$ & $4.0 \pm 0.7$ & $1.9 \pm 0.4$ & $1.6 \pm 0.4$ & $1.2 \pm 0.3$ \\
\hline Monocytes & $4.2 \pm 0.5$ & $8.8 \pm 1.5$ & $3.0 \pm 0.5$ & $2.7 \pm 0.7$ & $2.5 \pm 0.4$ \\
\hline Lymphocytes & $85.8 \pm 1.6$ & $66.2 \pm 4.9$ & $\begin{array}{c}78.1 \pm \\
0.9\end{array}$ & $\begin{array}{c}90.2 \pm \\
1.4\end{array}$ & $\begin{array}{c}90.6 \pm \\
0.9\end{array}$ \\
\hline
\end{tabular}

note: - *Recirculating Aquaculture Systems; ** Mean Corpuscular Hemoglobin.

When a part of fish in a sampling studied shows rather significant deviations from the group average, it indicates heterogeneity of the generation reared.

Alteration of leukocytic comprosition is an evidence of immunity and non-specific resistance reduction in this fish group. At this case, it is necessary to clear the reason of this deviation and to correct the situation formed.

It is not excluded that this is the organism's response to manipulations i.e. to impact of different negative factors connected with technological processes causing fish stress.

As it was above shown $[9,10,16]$ the main stress role consists in strengthening of adaptive organism's possibilities favouring its health. Alteration of different physiological reactions is noted in fish at stress. We recorded alteration of morphometric and biochemical blood and mucus parameters. In blood, they were manifested in decrease of thrombocytes number, leukocrit value and leukocytes quantity. The developing leucopenia is characterized by eosino-and-lymphopenia as well as by neurophilesis. Haemathological indices after stress are restored within 14-20 days.

It was proved that the most informative indices from characteristics of the mucus biochemical composition were alterations of hemoglobin, ketones and protein. Fluctuations of hemoglobin in fish mucus were between 25 and $200 \mathrm{er} / \mathrm{mcl}$, those of ketones between 0.05 and $2.1 \mathrm{mmol} / 1$, protein between 0.30 and $3.0 \mathrm{~g} / \mathrm{l}$, bilirubin from negative values to ++ au. These values allow to conclude the alteration of physiological organism status and to be criteria of stress and of its development rate.

Futhermore, it was found out, that manipulation results in reduction of feeding activity, what carp rehabilitate by the second day but sturgeon only by the fourth one (Fig.1). 


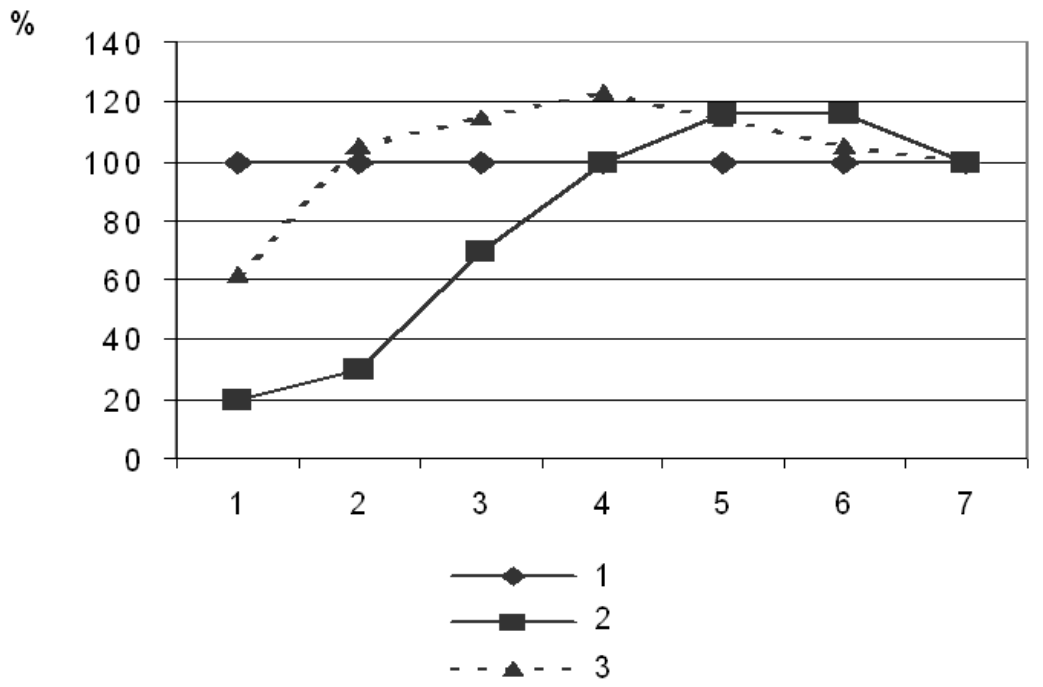

Fig.1. Dinamics of fish feeding activities after manipulation (\% from the control): 1 - control; 2 - Lena sturgeon after handling; 3 - carp after handling.

In fish stressed, one can observe reduction of non-specific resistance which results in rise of sensibility to deseases' agents. At low quantity, they act as stress-factors. Uniformity of non-specific blood reaction at low infection levels is manifested in leucopenia, lymphopenia and neurophylosis. While agents' quantity increase, one can observe different deviations in blood picture manifesting the acute disease development. Pathological shifts were of different character, but these alterations are non-specific. Anemy was recorded almost at all acute diseases. It was followed by decrease of hematocrit value, haemoglobin concentration and erythrocytes number, impacting erythropoiesis. The highest deviations were noted at carp branchiomycosis when these indices decreased almost by 2 folds in comparison with healthy fish.

Leucocytosis, characterized by agranulocytes' increase at inflammation of the swin bladder and at branchyomycosis in carp, was followed by activation of the lymphoidmacrophagal chain of the cell immunity. Decrease of neutrophils, eosinophils and monocytes numbers at ichthyophthiriasis, chilodonellosis and dactylogyrosis in carp is evidence of macrophagal chain migration to inflammation nidi. Leucopenia, observed at lingering agony in carp during aeromonosis and branchyomycosis as well as in the Caspian salmon at cryptobiosis, is connected with cells' lysis and other degenerative alterations in tissues.

\section{Discussion}

The blood analysis is one of the reliable and traditional methods used at physiological state appraisal of fish reared at commercial pisciculture as well as preparedness of young fish produced in fish culture plants at reproduction of valuable fish species.

Results of morphofunctional blood and mucus parameters studied revealed a possibility of principle to apply them for health control of fish reared in aquaculture.

Moreover, data received were to compare with the existing conception of physiological haemathological norm what is the most important mechanism at homeostasis support of fish under conditions of natural environment or maximally close to it at extensive stock densities $[2]$.

Physiological haemathological norm has been developed and may be used for a fish 
species taking into account its age and the season of rearing.

In modern aquaculture, different technologies of fish farming are applied which are different by stocking densities, hydrochemical regime, feeds used and other factors reflecting intensity of metabolic processes in fish organsm and its growth rate. Under these conditions, blood lability manifests itself in alteration of its values.

In view of it, we suggest to introduce the conception of «haemathological technological norm», since the range of its values is a little wider, than those of «physiological norm», because it reflects adaptive reactions of fish organism to environmental factors and provides its homeostasis under new conditions depending on rearing technology used. For wide use of the «haemathological technological norm», it is necessary to create the values bank for blood parameters of each aquculture object and to correct it taking into account fish age groups and technologies of pisciculture. The lack of those data hindered the analysis of results received at fish health control and included their comparison with already existed in literature data of «physiological norm».

At fish growing in aquaculture, adaptive mechanisms manifested themselves often in stress reactions as a response to influence of different negative factors connected both with technological processes and reaction to invasion of disease agents into fish organism. The first stress reaction (the stage of alatm or mobilization) became apparent in forming of a common adaptive syndrome, increase of non-specific resistance, which was characterized by development of adaptive reactions in some stress-reactive species.

It was reflected in wide spread in values of morpho-functional blood and mucus indices at their determination for fish groups investigated.

It was observed that fish at further stress development into resistance stage showed decrease of non-specific resistance revealing in leucopenia, lymphopenia and neutrophilesis. These values allowed to ascertain weakened species part and to assess the situation formed.

When the stress-factor is not eliminated, so even by high fish adaptive abilities one can ascertain either adaptability to changed life conditions or the process came into emaciation stage, following by different dystrophic processes, non-reversible alteration of metabolism and even by fish death (the 3rd stage of a stress is emaciation), as a result of defensive potential-compensatoric organism's opportunities decreased.

In such stage, the organism attains its limits of physiological adaptation. At presence of diseases agents, which do not act as stress-factors at high numbers, fish blood reacts like typic one for the alarm stage.

Different deviations in blood picture are noted at agents number increase and during development of clinical diseases signs what was evidence of the pathological process presence. The study of pathogenesis at eleven diseases of fish showed that deviations, revealed for blood picture and biochemical mucus composition, were of different character, but these alterations are non-specific ones.

The haemathological analysis, carried out by a classical method, seems to be labourintensive one, requiring high qualificated specialists in the field of haemathology. Thus, its use in aquaculture is rather limited what seems to be a sufficient disadvantage at ichthyopathological investigations. Recently, medicine and veterinary practice use widely automatic and semi-antomatic analysers, allowing quickly and qualitatively to carry out investigations of blood. We developed and refined an express-method of stress-diagnostic in fish with use of gluco-and multisticks. Their application allowed us timely and intravitally to determine up to 10 biochemical parameters in mucus as well as glucose in blood within 2-3 minutes.

Thus, investigations, carried out on use of morphofunctional blood and mucus indices, showed possibility of their application at health control of fish reared in aquaculture. They enable timely enough to reveal decrease of nonspecific resistance in stress-reacted species, to analyse the situation and to provide correcting measures. In future, it is nessessary to 
develop and to practice expressive methods and automatic systems for fish blood analysis with a view to increase the objectivity and routine monitoring of haemathological investigations at health control of aquaculture objects.

\section{Conclusions}

1. Application of morphofunctional blood and mucus characteristics anables to assess objectively and to reveal a species group with decreased immune status at fish health control. 2. For timely fish health control, the following blood parameters are informative: hemoglobin content, glucose concentration, erythrocytes and leukocytes numbers, erythropoieses activity, leucocytic composition. Those of biochemical mucus composition are hemoglobin, ketones and protein.

3. It was shown that non-specific resistance level of fish, reared in quaculture and adaptive abilities of some species had an effect on heterogeneity of values determined, what makes possible to reveal the weakened species part and to estimate necessity for carrying out of correcting actions as well as to predict an outcome of the situation formed.

4. An express-method of stress-diagnostic in fish has been developed and refined with use of gluco-and multisticks. Their application makes it possible to determine timely and intravitally up to 10 biochemical mucus parameters and blood glucose within 2-3 minutes.

\section{References}

1. R.J. Roberts, Fish Pathology, 571 (Oxford: John Wiley \& Sons, 2012)

2. E.V. Mikodina, T.I. Larteva, M.A. Sedova, E.V. Ganzha, E.D. Pavlov, Fich Functional Markers: Henbook, 1-11 (VNIRO Publishing, 2016)

3. G. Scapigliati, Functional aspects of fish lymphocytes, Developm. Comp. Immunology 41, 200-208 (2013)

4. S.J. Gholami-Seyedkolaei, A. Mirvaghefi, H. Farahmand., A. A. Kosari, Effect of a glyphosate-based herbicide in Cyprinus carpio: Assessment of acetylcholinesteraseactivity, hematological responses and serum biochemical parameters, Ecotoxicol. Environ. Safety. 98, 135-141 (2013) doi:org/10.1016/j.ecoenv.2013.09.011

5. Y. Filizadeh., H. Rajabi Islami, Toxicity determination of three sturgeon species exposed to glyphosate, Iran. J. Fish. Sci. 10(3), 383-392 (2011)

6. T.A. Suvorova, G.I. Pronina, D.V. Mikryakov, A.B. Petrushin, Aktual'nye voprosy veterinarnoj biologii 2(42), 38-41 (2019) doi: 10.24411/2074-5036-2019-10023.

7. D.L. Aboagye, P.J. Allen, Effects of acute and chronic hypoxia on acid-base regulation, hematology, ion, and osmoregulation of juvenile American paddlefish, J. Comp Physiol B 188, 77-88 (2018) doi:10.1007/s00360-017-1104-7.

8. R. A. Zaprudnova, Transactions of IBIW 78(81), 90-101 (2017) doi:10.24411/03203557-2017-10016.

9. J.M Koolhaas, A. Bartolomucci, B. Buwalda, S.F. de Boer, G. Flügge, S.M. Korte, et al., Stress revisited: a critical evaluation of the stress concept. Neurosci Biobehav Rev., 1291-1301 (2011) doi:10.1016/j.neubiorev.2011.02.003.

10. O. G. Petrova, O. V. Badova, D. N. Rechkalov, Agrarian bulletin of the urals, 09(176), 44-50 (2018) doi: 10.32417/article_5be295333d9241.77601819 
11. T. Ellis, H.Y Yildiz, J. López-Olmeda, M.T. Spedicato, L. Tort, Ø. Øverli, et al. Cortisol and finfish welfare, Fish Physiol Biochem 38, 163-188 (2012) doi: 10.1007/s10695-0119568

12. A.R. Khansari, J.C. Balasch, E. Vallejos-Vidal, D. Parra, F.E. Reyes-López, L. Tort, Comparative immune- and stress-related transcript response induced by air exposure and Vibrio anguillarum bacterin in rainbow trout (Oncorhynchus mykiss) and Gilthead Seabream (Sparus aurata) Mucosal Surfaces, Front Immunol 9, 856 (2018)

13. F.S. Habhar, Effects of stress on immune function: the good, the bad, and the beautiful, Immunol Res 58, 193-210 (2014) doi: 10.1007/s12026-014-8517-0

14. D.V. Mikryakov, G.I. Pronina, T.A. Suvorova, A.B. Petrushin, Trudy VNIRO 175, 104 111 (2019)

15. J. J. Havixbeck, D.R. Barreda, Neutrophil Development, Migration, and Function in Teleost Fish, Biology (Basel) 4(4), 715-34 (2015) doi:10.3390/biology4040715.

16. V.R. Mikryakov, D.V. Mikryakov, Immunological Indication of Fish Health, Journal of Ichthyology 55(1), 143-146 (2015) doi:10.7868/S0042875215010129

17. M.F. Subbotkin, T.A. Subbotkina, Inland Water Biology 11(2), 184-194 (2018) doi:10.1134/S1995082918020037

18. M.F. Subbotkin, T.A. Subbotkina, Journal of Applied Ichthyology 27(2), 213-218 (2011) doi:10.1111/j.1439-0426.2010.01644 